\title{
Differentiation of sheep milk and cheese based on quality and composition
}

\author{
Raúl R. Vera, Claudio Aguilar, and Rodrigo Lira \\ Departamento de Ciencias Animales, Facultad de Agronomía e Ingeniería Forestal, Pontificia Universidad \\ Católica, Casilla 6177, Santiago, Chile
}

\begin{abstract}
R.R. Vera, C. Aguilar, and R. Lira. 2009. Differentiation of sheep milk and cheese based on their quality and composition. Cienc. Inv. Agr. 36(3):307-328. Traditional sheep production for meat and wool for meat and wool among small and medium-sized Chilean farmers has low profitability. Therefore, there is interest in producing value-added, differentiated products. One alternative is the production of sheep milk and cheese. This article analyzes and discusses existing alternatives for modifying milk and cheese compositions with the aim of differentiating these products. Also, analytical techniques that allow the chemical characterization of milk and cheese are briefly mentioned. The main international thrusts are focused on the modification of the content and composition of milk fatty acids and on the identification of volatile compounds, terpenes, polyphenols and other analytes that allow differentiation of cheese types on the basis of aroma, taste and flavor and that would help in ensuring traceability.
\end{abstract}

Key words: Cheese, differentiation, flavor, milk composition sheep value-added.

\section{Introduction}

The profitability of traditional sheep production for meat and wool among small and mediumsized producers in the Central Region of Chile is low (Aguilar, unpublished report); therefore, there is interest in diversifying production and finding alternatives offering a higher added value. One possibility is quality milk and cheese production. The objective of this review is to carry out a critical analysis of the scientific literature and to determine what factors contribute to the differentiation of these products. For that purpose, the current state of knowledge on sheep milk production in Chile is analyzed, and its composition and the possible effects on human health are discussed, followed by a review

Received 17 July 2008. Accepted 27 November 2008. Corresponding author: rverai@uc.cl of the international literature regarding existing alternatives for modifying milk composition by alterations of animal diet.

\section{Sheep milk in Chile}

The feasibility of sheep milk production in Chile was analyzed at an international seminar in 1998 organized by the Instituto de Investigaciones Agropecuarias (INIA) with the sponsorship of the Fundación de Innovación Agraria (FIA), Fondo de Desarrollo e Innovación FDI and Intendencia Regional de Aysén (Hepp, 1998), where background information on milk production in Magallanes, in the Chacabuco Valley, and in the Simpson Valley was presented. Kusanovic (1998) reviewed sheep milk production in Corriedale sheep and Corriedale x Milchschaf crosses (Kusanovic, 1998) in Magallanes. The former produced $498 \mathrm{~g}$ daily, with a total lactation of 
$29 \mathrm{~L}$, while the crossbred ewes produced $853 \mathrm{~g}$ daily with $70 \mathrm{~L}$ per lactation. The fat contents were 6.4 and $4.5 \%$ respectively, while the ratios of milk volume to cheese weight were 5.3 and 6.2 , respectively. The maturation times of the cheeses were 2-4 months, and the least mature cheeses were better accepted by untrained tasters. The same genotypes mentioned before were tested in the Valley de Chacabuco, Aysén (Hervé and Vidal, 1998) with milk productions slightly higher than in the previous case, but showing the same tendencies, although the results were not directly comparable due to management differences. In INIA, Tamel Aike (Hepp, 1998) several breed groups were compared under grazing conditions, supplemented daily with $100 \mathrm{~g}$ of oats, with the following results in total and daily milk production, respectively: Corriedale, $5.6 \mathrm{~L}$ and 0.381 L; Border Leicester, 46.7 and 0.397; Milchschaf, 120 and 1.076; Border x Corriedale, 59 and 0.403; Dorset x Corriedale, 61 and 0.466; and Suffolk x Corriedale 113.5 and 0.709.

In the Central-South zone of Chile (Cauquenes), Avendaño et al. (2002) compared 50\% Milchschaf sheep with Suffolk animals and local sheep, the latter with a predominance of blackface sheep, that were grazed on sown pastures and supplemented with alfalfa hay and concentrates. The total milk volumes produced by these breeds were 140, 104 and $125 \mathrm{~L}$ per animal in 181,176 and 175 days of milking respectively, corresponding to mean daily productions of 773 , 589 and $706 \mathrm{~mL}$. The mean fat contents were $6.18,6.71$ and $6.63 \%$, respectively. From these reports, as well as others quoted by Avendaño et al. (2002), it may be inferred that significant productions of sheep milk and cheese are possible in different regions of Chile, depending on the animal genotype and feeding.

\section{Dairy products and human health}

There is a strong relation between the consumption of animal products, their composition and the incidence of chronic diseases in humans, although it has been difficult to establish causal relations among these factors (Lucas et al., 2005). There is epidemiological evidence positively correlating the incidence of cardiovascular diseases and lipid consumption, in particular cholesterol and fatty acids. Saturated fatty acids represent 58 to $82 \%$ of total milk lipids, and they have been associated with hypercholesterolemia and increased levels of low-density lipoproteins (LDL), particularly in the case of palmitic, myristic and lauric acids (Pacheco et al., 2006). On the other hand, dietary mono- and poly-unsaturated acids would reduce those risks, increasing high-density lipoproteins, HDL (Huth et al., 2006). Other aspects of dairy products that may contribute to modifying the risks of chronic diseases relate to the incidence of osteoporosis and some types of cancer (Lucas et al., 2005). De Renobales et al. (2008) have discussed in detail the lipid compositions of milk and cheeses in relation to human health.

Regardless of these facts, it must be acknowledged that animal products have a lipid profile different from that currently recommended for humans (Durand et al., 2005) (Table 1), but, fortunately, the composition in terms of these groups of fatty acids as well as from specific fatty acids is plastic and may be modified by altering the animal diet (Chilliard et al., 2000). For example, the concentration of rumenic acid (C18:2, cis-9, trans-11; one of the conjugated linoleic acids or CLA) may vary by more than $300 \%$.

Table 1. Recommended fatty acid composition of the human diet compared with the composition of cow milk and beef.

\begin{tabular}{lccc}
\hline Fatty acids & Recommendation & Cow milk & Beef \\
\hline Saturated, \% & 25 & 70 & 50 \\
Monounsaturated, \% & 60 & 25 & 44 \\
Polyunsaturated, \% & 15 & 5 & 6 \\
\hline
\end{tabular}

Source: Durand et al. (2005). 


\section{Quality of animal products}

The concept of quality has been defined in different ways, varying widely among countries. For example, in Northern Europe it is associated with the fulfillment of sanitary standards and other regulations, while the concept is much wider in Southern Europe, including considerations related to sensorial properties, the region of origin, the production system and the producer groups or human societies as well as considerations of animal welfare. However, there is a tendency in most of the world to discriminate products according to known nutritional features, such as the content of saturated lipids, cholesterol, different micronutrients and compounds considered to be "nutraceutical" (Hocquette et al., 2005). It is noteworthy that the concept is dynamic and subject to continuous gradual changes according to the evolving perceptions of the consumers and the influence of official regulations as well as the growing body of nutritional knowledge and the influence of diverse pressure groups.

\section{Differentiated sheep products}

In Chile, most small sheep producers have limited access to modern technology; they merely sell undifferentiated products with low added value, such as meat and wool. The opportunity to intensify the production of these systems by traditional means is limited and with low private profitability, but with high social profitability in the case of product differentiation (Aguilar, unpublished report).

Regarding the development of differentiated and functional products, it has been shown that it is possible to produce lambs with an altered lipid profile improved for human health over traditional products, with better atherogenic and thrombogenic indices than average ruminant meats, by the inclusion of byproducts of olive oil extraction (olive oil pomace or "alpeorujo") in their diet. This would involve a qualitative and quantitative change for the existing production systems (Aguilar et al., 2008; Vera et al., 2008). These results may be applicable to milk production as well, since the mammary gland of ruminants only synthesizes fatty acids of up to 16 carbons long, with the remainder originating from body fat mobilization and dietary sources modified by rumen fermentation. In addition, the studies carried out in the U.S.A., New Zealand and in Mediterranean Europe have clearly shown that directly grazed forage increases the content of polyunsaturated fatty acids, improves the omega-6/omega-3 ratio and increases the content of conjugated linoleic acid (CLA) in meat and milk (Palmquist, 2006; Schroeder, 2004).

\section{Composition and yield of sheep milk}

The average composition of sheep milk includes $7.1 \%$ fat, $5.7 \%$ protein, $4.8 \%$ lactose, $9 \%$ ash and $11.5 \%$ non-fatty solids (Treacher et al., 2002). Fat and protein contents are high in early lactation, decrease during the lactation peak and then increase again as the milk yield diminishes. Lactose content shows little variation, as its synthesis determines the rate of daily milk production, but the negative relation between yield and fat and protein contents holds generally, regardless of whether milk yield is a result of genetics, variation among individuals or selection processes (Bencini et al., 1997; Treacher et al., 2002; Bencini et al., 2003). These variations imply that the milk energy content may vary between 3.8 and $5.5 \mathrm{MJkg}^{-1}$. The relation between milk energy $\left(\mathrm{E}, \mathrm{MJkg}^{-1}\right)$, milk fat content $(\mathrm{F}$, $\left.\mathrm{gkg}^{-1}\right)$ and lactation days (D), calculated for 92 records of milk production from Merino (7.2\% fat) and Border Leicester (10.5\% fat) sheep, was reported to be as follows(Brett et al., Treacher et al., 2002):

$$
\mathrm{E}=0.0328 \mathrm{~F}+0.0025 \mathrm{D}+2.20, \quad \mathrm{RSD}=0.14
$$

Milk fat consists mainly of triglycerides ( $>95 \%$ of the total fat in bovine milk; Jensen, 2000) composed mainly of monounsaturated fatty 
acids with $14-18$ carbons, followed by a minority $(22 \%)$ of fatty acids with four to ten carbons (Treacher, 2002). These short-chain fatty acids (butyric and caproic) are found only in milk, not in any other ruminant tissues, and are esterified almost exclusively at the third carbon of the glycerol molecule (Lundén et al., 2005). Table 2 compares the fatty acid compositions of sheep milk and those of other species. Milk fat includes a large amount of fatty acids in amounts smaller than $1 \%$ of the total, and Jensen (2000) lists over 400 fatty acids found in bovine milk. Nevertheless, only 20 to 30 fatty acids are currently considered to be of nutritional significance. Free fatty acids $(<1 \%$ of the total), and fatty acids released by lipases from different origins, are extremely important in determining cheese flavor (Jensen, 2000; McSweeney and Sousa, 2000). Determination of free fatty acids requires specific methods of extraction and derivatization (Yurawecz et al., 1999; Ostrowska et al., 2000; Pinho et al., 2002).
Casein is the main protein in milk, present in several isoforms, all of which have high proline contents and are found in complexes with $\mathrm{Ca}$ and P. In addition, milk proteins include beta-lacto globulin and alpha-lacto albumin, with traces of immunoglobulins (Treacher et al., 2002).

Milk fat is partly synthesized in the mammary gland, in particular fatty acids up to 16 carbons long, while longer-chain fatty acids arise from mobilized adipose tissue, the diet and from rumen metabolism. The contribution of these different sources is influenced by the energy balance of the animal, lactation status and nutrient balance. On average, the proportions provided in milk cows by these three sources to the total fatty acid content is estimated to be in the ratio of 1:0.2:0.9 (Walker et al., 2004). Conversely, lactose and proteins are synthesized entirely in the udder from glucose and glycerol in the first case, and blood amino acids in the case of proteins.

Table 2. Fatty acid compositions of milks of different origins

\begin{tabular}{lrrrr}
\hline & \multicolumn{3}{c}{ Fatty acids $^{1}, \%$} \\
\cline { 2 - 5 } C4:0 & Ewe & Goat & Cattle & Human \\
C6:0 & 3.17 & 3.63 & 3.61 & 0.25 \\
C8:0 & 2.22 & 2.51 & 1.97 & 0.25 \\
C10:0 & 2.22 & 2.79 & 1.31 & 0.25 \\
C12:0 & 6.35 & 7.26 & 2.62 & 1.27 \\
C14:0 & 3.81 & 3.35 & 2.95 & 6.33 \\
C16:0 & 10.48 & 8.94 & 11.15 & 7.85 \\
C18:0 & 25.71 & 25.42 & 28.85 & 23.29 \\
C16:1 & 12.29 & 13.11 & 7.34 \\
C18:1 & 2.29 & 2.23 & 2.62 & 3.29 \\
C18:2 & 2.06 & 27.37 & 27.54 & 37.47 \\
C18:3 & 2.76 & 3.07 & 2.62 & 9.37 \\
C20:4 & 2.86 & 1.12 & 1.64 & 1.27 \\
C20:1 & 2.06 & & & 0.76 \\
\hline
\end{tabular}

${ }^{1}$ Each value is the \% of the total fatty acids Source: Haenlein (2000).

The variation in milk yield between breeds is large. In meat breeds selected for lamb production, the maximum daily yield is $2-4 \mathrm{~kg} \cdot \mathrm{day}^{-1}$, with total yields of 150-200 kg over lactations of three months in twinning sheep, and $90-160 \mathrm{~kg}$ in ewes with a single lamb. In small breeds and in wool breeds, e.g., Merino, the expected yields are lower. Variation is higher in dairy breeds, particularly when they are subject to selection; for example, in East Friesland and Assaf, yields 
of $600-1,000 \mathrm{~kg}$ in much more extended lactations are possible, while Mediterranean breeds such as Lacaune, Manchega, Churra, Latxa, Manech and Sarda produce 150-250 kg of milk during 200 days of milking after suckling a lamb for one month (Treacher et al., 2002).

In sheep milk production systems, the beginning of milking at 30 days of lactation results in a marked fall of milk yield, which oscillates between 29 and $55 \%$, depending on previous management of the suckling period (restricted versus non-restricted respectively; Labussiere et al., 1969). However, when the available forages are of lower quality, maximum voluntary consumption occurs later (at 3-4 months from parturition), and the milk yield is certainly also lower without supplementation, although the lactation peak continues to occur at approximately 30 days. On Lolium perenne-based pastures, milk production and forage intake peak when the pastures are maintained at $5-12 \mathrm{~cm}$ high (3 $\mathrm{cm}$ generally represents $1,000 \mathrm{~kg} \mathrm{MSha}^{-1}$; Freer et al., 2002) and forage intake is maximized at four weeks of lactation (Treacher et al., 2002).

Transformation of milk into cheese involves different fermentative processes that use the macronutrients present in milk as substrates. Table 3 shows these relations.

Table 3. Chemical compounds responsible for the flavor of Cheddar cheese and their relationship to substrates found in milk.

\begin{tabular}{lll}
\hline Compound & Compound & Compound \\
\hline Casein & Fat & Lactose and citric acid \\
Peptides & Fatty acids & Lactate \\
Amino acids & Keto acids & Pyruvate \\
Acetic acid & Methyl ketones & $\mathrm{CO}_{2}$ \\
Ammonia & Lactones & Diacetyl \\
Pyruvate & & Acetoin \\
Aldehydes & & 2,3 -butanediol \\
Carboxylic acids & & Acetaldehyde \\
Sulfur compounds & & Acetic acid \\
& & Ethanol \\
\hline
\end{tabular}

Source: Singh et al. (2003).

\section{Variations in milk composition}

The influence of nutrition on ruminant milk composition has been of interest for many years, and it has been the subject of extensive and detailed reviews in the literature (Alderman et al., 1997; Demeyer et al., 1999). The refinement of the analytic techniques and the growing interest in micronutrients, nutraceutical and functional foods and similar products led to continuous advances in these subjects (Chilliard et al., 2000), which are briefly summarized below.

The main source of nutrients for sheep is, in general, the forage directly grazed, and grains and concentrates to a much lesser degree. From the point of view of sheep milk composition, lipid content is particularly important among ma- cronutrients. In general, forages contain 3-4\% of lipids composed of a mixture of mono and digalacto-1,2-diglycerides, along with waxes, pigments and cutin, while triglycerides are predominant in grains. Both have $\mathrm{C} 18$ polyunsaturated fatty acids, but linolenic acid is predominant in forage galactolipids and linoleic acid in grains. Comparative studies have shown considerable variation in the profile of fatty acids across grass species and among cultivars within species (Dewhurst et al., 2001).

Enzymatic activity in the rumen saturates 85 $100 \%$ of the linolenic acid and $70-95 \%$ of the linoleic acid. Linoleic acid gives rise to C18:2, cis-9, trans-11 (rumenic acid, one of the CLA isomers) via isomerization, a small proportion of which escapes the rumen, and the rest is saturated into stearic acid (Annison et al., 2002). 
Conjugated linoleic acids (CLA) constitute a group of geometric and positional isomers of C18:2 linoleic acid, 28 of which may potentially exist (see for example, Jensen, 2000). The main CLA is rumenic acid, while trans -10 , cis- 12 acid has also raised interest due to its ability to inhibiting triglyceride synthesis in experimental models.

Oleic acid is the most abundant mono-unsaturated fatty acid in milk (approximately $8 \mathrm{~g} \cdot \mathrm{L}^{-1}$ in cow milk, or $25 \%$ of the total fat), so that milk and dairy products represent the main source of that acid for human diets in many countries (Haug et al., 2007). Oleic acid may contribute to decreased plasma cholesterol and triglycerides (Kris-Etherton et al., 1999). With regard to oxidative processes in the human body, oleic acid is more resistant to oxidation than omega- 3 and -6 fatty acids. The studies carried out have shown that a diet with a high mono/polyunsaturated ratio provides better protection against heart diseases than a diet rich in polyunsaturates alone (De Lorgeril et al., 1994; Nicolosi, 2004).

Dietary micronutrients also affect milk composition significantly. Lucas et al. (2005) compared milk composition produced by cows grazing spring pastures in France with the milk produced based on concentrates or hay, and reported significant differences in several important micronutrients for human health, as shown in Table 4. In addition, several of the chemicals found in milk may potentially alter the rheological properties of cheese, as well as its appearance and flavor (McSweeney and Sousa, 2000).

Table 4. Selected micro-nutrients found in cow milk produced associated with concentrate versus hay-based diets (numbers are percentages relative to grazing)

\begin{tabular}{lcc}
\hline Micro-nutrient & Concentrate diet, $\%^{1}$ & Hay diet, $\%^{1}$ \\
\hline Vitamin A & 85 & 65 \\
Beta-carotene & 63 & 47 \\
Vitamin E & 73 & 75 \\
Saturated fatty acids & 124 & 117 \\
Monounsaturated fatty acids & 54 & 63 \\
Polyunsaturated fatty acids, n6 & 163 & 100 \\
Polyunsaturated fatty acids, n3 & 36 & 100 \\
Vaccenic acid, C18:1 trans-11 & 19 & 38 \\
Conjugated linoleic acid (CLA) & 24 & 41 \\
Phenolic compounds & 22 & 41 \\
\hline Source: Lucas et al. (2005). & & \\
${ }^{1}$ Number are percentages relative to grazing. & &
\end{tabular}

The variations shown in Table 4 clearly suggest that the nutritional properties of dairy products may be altered by manipulating the feeding strategy. For example, the $24 \%$ increase in saturated fatty acids (undesirable from the point of view of human health) and the $80 \%$ decrease in CLA found with the concentrate diet constitute large and nutritionally significant changes. Another striking aspect is that several components of nutritional interest may change in parallel. For example, the increase of polyunsaturated fatty acids in the grazing diet is closely accompanied by antioxidant elements such as vitamin $\mathrm{E}$, carotenes, and polyphenols, while, on the contrary, the increase of saturated fatty acids in the diet with concentrates and hay was accompanied by a decrease in trans- fatty acids, such as vaccenic acid, a precursor of CLA.

Forages have high concentrations of polyphenols in relation to other feeds. Bioavailable polyphenols include flavonoids and other hydrolyzable polyphenols (a fraction of the tannins and phenols that are present in the plant cell wall; Besle et al., 2005). INRA (France) researchers have studied the extent to which these compounds are transferred to bovine milk since they may be used to discriminate among milks by origin, 
with implications for the traceability of dairy products. With that purpose, they compared six different diets, including a diet rich in concentrates, and diets based on maize and Lolium silage, Lolium hay, and hay and forage from native pastures in the Alps. Simple polyphenols and flavonoids, extracted with a water:ethanol solution, were emphasized. The concentrations found varied between 0.8 and $8 \mathrm{gkg}^{-1} \mathrm{MS}$, with maximum values found in the native pastures; the consumptions of those compounds varied between 35 and $148 \mathrm{~g}$ daily. A total of 54 simple polyphenols were identified in the various milks by High Pressure Liquid Chromatography (HPLC), at levels of 4-10.8 $\mathrm{gL}^{-1}$ milk, where the extremes correspond to concentrates and pastures respectively, but fewer than ten of these were useful in differentiating the diets, as most of the rest were probably degradation products from the consumed polyphenols. In principle these degradation products could also be used as tracing elements of the diet.

The nutritional properties mentioned above are also altered by processing milk into butter, cheese and other dairy products. In addition, the composition varies strikingly with the type of cheese (Lucas et al., 2005). As an example, a Gruyere cheese has approximately 50\% higher lipid content than a Camembert cheese. These processes also influence the content of vitamin $\mathrm{B}$ and several minerals; vitamins are influenced by water solubility, and minerals are influenced because they can also be solubilized and mixed in serum, depending on the degree of acidification during milk fermentation.

\section{Modifications of milk composition}

It is likely that the incorporation of diet components into milk is more dynamic than into meat since milk quickly acquires attributes from the feed consumed by the animal (Sanz Sampelayo, 2007; Scintu, 2007; Walker, et al., 2004), which may provide "typicity" features. Those features have been demonstrated, among others, for cheeses such as the Greek Feta (Zlatanos, 2002), the Fontina Valle d'Aosta (Berard, 2007) and the Idiazabal of the Basque Country (Larráyoz et al., 1999; Barron et al., 2005b).
On the other hand, further information on the possible effects of the physical-chemical modifications of milk originated by feeding strategies on the rheological properties of the resulting cheeses is required. So far, the studies available regarding the effects of pasture management and supplementation with sources of conjugated linoleic and mono-unsaturated acids have shown positive effects on those properties (Buchin et al., 1999; Foegeding et al., 2007; Park et al., 2007), but this topic is still under investigation.

Studies in New Zealand have shown that some forages, such as Lotus corniculatus, transfer polyphenols to grazing sheep, with diverse beneficial attributes based on their anti-oxidant effects, control of helminths and increased ewe fertility (Barry et al., 2001, Ramírez Restrepo et al., 2005). However, studies on the effect of $L$. corniculatus on milk properties have not been published, although a recent study of compounds affecting the flavor of lamb meat has not demonstrated negative effects; on the contrary, it provides some evidence in favor of the decrease of compounds such as skatole and indole associated with the undesirable ram smell (Schreurs et al., 2007).

Other forage species may have comparable features. Studies conducted in the Mediterranean region (Addis et al., 2005; Cabiddu et al., 2005; Ramalho Ribeiro et al., 2006) have shown that some species, in particular some dicotyledons, have secondary metabolites that are transmitted to animal products, giving differentiating organoleptic features. If these findings were applicable to the Mediterranean climatic region of Chile, there would be an additional economic stimulus to improve the forage resources of the region (Ovalle and Squella, 1996), fostering and adding value to those natural resources and, at the same time, leading to the elaboration of clearly differentiated animal products.

\section{Supplementation of dairy sheep with lipids}

The energy requirements of early lactation in the cow, ewe and goat are very high and may not be satisfied by voluntary consumption of 
conventional diets. Therefore, the effect of supplementation with lipids has been studied to increase the energy density of feeds. Conventional diets of ruminants habitually contain less than $3.5 \%$ of ether extract (EE), and between 20 and $50 \%$ of that fraction are compounds other than fatty acids, including products such as waxes, pigments like chlorophyll, and other non-saponifiable compounds (Sukhija and Palmquist, 1988). Fat addition to diet affects dry matter intake, which generally diminishes if fat content is higher than $6 \%$; the reasons for this are not clear and have been the subject of numerous hypotheses, including the idea that it may modify the molar relations of volatile fatty acids in rumen, in addition to affecting the microbial population of rumen. Therefore, when fat supplements have been added, fatty acids have been saponified to calcium soaps, so that they escape ruminal fermentation.

Supplementation with unprotected lipids (for example, vegetable oils) to increase the content of EE to $5.7 \%-6.0 \%$ has resulted in some cases in a decrease of butirometric fat, while in other cases fat content was unaltered with a concomitant increase of milk yield. In any case, the changes induced by supplementation in sheep seem to be lower than in cows, and the authors concluded that more information on the use of unprotected lipids in dairy sheep is still required.

Calcium soaps of fatty acids have been used in dairy sheep. Mele et al. (2004) have reviewed the existing literature, and point out that references on this type of supplementation in sheep are limited, compared with the results in cows, with exception of the use of calcium soaps of palm oil (a somewhat undesirable oil, due to its high content of palmitic acid). Supplementation with calcium soaps for dairy ewes has provided consistent results, increasing milk yields and milk fat percentage. For example, the inclusion of $5-7 \%$ of calcium soap of olive oil increased fat yield 5-8\%, without affecting the milk yield (Mele et al., 2004), and increased the C18:1 content, although whether the increase was oleic acid or other C18:1 isomers was not determined. In vitro studies have shown increases of these isomers (Mosley et al., 2002), and analyses of cheeses have reported very significant increases of vaccenic acid (de Renobales et al., 2008). In fact, sheep milk in particular, has a very high content of vaccenic acid (Cabiddu et al., 2005).

Supplementation with different vegetable oils has also been tested to increase milk CLA content. Luna et al. (2008) supplemented goat diets with 0.81 or $1.84 \%$ of sunflower oil or linseed oil respectively over a period of three months. The alpha-linolenic acid content of milk in the control diet was $0.35 \%$, which increased to $0.62 \%$ with supplementation, and the total CLA rose from 0.46 to $1.18 \%$, with the vaccenic acid increased from 1.38 to $4.05 \%$. The increase in this acid was positively correlated with the increase of rumenic acid, while changes in other isomers were small. Similarly, Gomez-Cortes et al. (2008) supplemented a dairy sheep diet with soybean oil and observed that the total CLA content increased from 1.04 to $3.44 \mathrm{~g} / 100 \mathrm{~g}$ of total fatty acids, while vaccenic acid increased

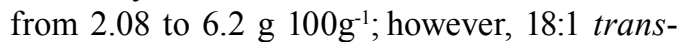
fatty acids also increased. Supplementation did not affect milk yield or fat content. It has also been verified that a CLA increase in milk and cheese may be associated with significant but modest and acceptable flavor modifications (Sinclair et al., 2007).

It should be noted that the separation of the CLA isomers is tedious and may not be achieved with a single analytical technique (Luna et al., 2005b), although in some circumstances, relatively fast identification of important isomers is feasible (Moltó-Puigmartí et al., 2007).

\section{Milk production and differentiated sheep cheese from forages and other feeds}

As indicated before, it is feasible to alter milk composition, but not the protein content or its composition, except in extreme feeding conditions. Many of these possible modifications are harnessed in lamb, calf, milk and cheese production with "typicity" features, which have led to denominations of origin and other forms of protection of the respective products (Scintu et al., 2007). Many of these differentiating features are associated with the fatty acid profiles induced by different feeds, including polyun- 
saturated fatty acids, uneven-chain fatty acids and branched-chain fatty acids (Vlaeminck et al., 2006). Thus far, special emphasis has been placed on reducing intermediate-chain fatty acids (C10 a C16), and increasing oleic acid to reduce cardiovascular risks as well as augmenting vaccenic acid and rumenic acid due to the demonstrated anticarcinogenic effect of the latter two in experimental animals (Dewhurst et al., 2006). Supplements based on marine, vegetable and oils protected as soaps have been used for that purpose, while the composition and potential contribution of forages that generally constitute the feeding base has received less attention (Dewhurst et al., 2006).

Bu et al. (2007) compared soybean oil, linseed oil or a mixture of both ( $4 \%$ of the total diet) as a supplement for dairy cows and demonstrated that the contents of vaccenic acid in the milk were increased by 318,105 and $206 \%$ respectively, compared to the control diet, while CLA was increased 273,150 , and $183 \%$, respectively, clearly indicating that the supply of some polyunsaturated acids can increase the content of desirable fatty acids in cow milk.

In contrast with routine analyses of total fat, protein and lactose, methods for the detailed analysis of milks and cheeses, particularly the latter, are very demanding given the complex matrix presented by cheese, requiring sophisticated equipment such as gas chromatography with mass spectrometry (GC/MS) if the aim is to identify minor chemical compounds that contribute to product differentiation. These methods have been discussed in detail by Singh et al. (2003) for the case of Cheddar cheese, but the considerations made are applicable to other cheeses as well (see for example Kirk et al., 2006). GC/MS allows the precise identification of unknown compounds when the instrument output in terms of mass and mass/charge relation is compared with international databases. In fact, this methodology is considered the most important among the analytical methods available (Rubinson and Rubinson, 2000). In applications of this nature, Singh et al. (2003) gave a long list of secondary products, many of them volatile, originating during cheese fermentation from proteolysis, lipolysis and fermentation of carbohydrates and organic acids (for example citric acid), which indicates the complexity of the processes involved and the variety of final products, to the extent that, so far, the synthetic reproduction of all the organoleptic features of cheese has been impossible. Furthermore, if the identity of the differentiating chemical compounds is known, and pure standards are available, they can be quantified by analysis of headspace with gas chromatography equipped with an FID detector or by solid phase microextraction (SPME) and/or other techniques (Stephan et al., 2000).

Volatile compounds are numerous in cheese, but only a small fraction of these are responsible for flavors (Pinho et al., 2002; McSweeney and Sousa, 2000; Sablé and Cottenceau, 1999). Cheese made from raw sheep milk has a marked and distinctive flavor due to its high fat content, which is associated mainly with free short- and medium-chain fatty acids, which are abundant as result of lipase activities of animal origin as well as of microorganisms. Each of these fatty acids has a particular smell. Long-chain fatty acids $(>12 \mathrm{C})$, although abundant in cheese, make a small contribution to cheese flavors. In general, important chemical and organoleptic differences between different cheeses have been found, even within the same type of cheese produced in different environmental conditions. These differences are generally associated with the content and composition of free fatty acids, particularly short-chain fatty acids (Poveda et al., 2006). Another important differentiating element is the type of rennet used, which may alter markedly cheese flavor by modifying numerous chemical parameters, including the content and type of free fatty acids (Larráyoz et al., 1999; Virto et al., 2003).

The number of experiments reported in literature on the effect of forages on the organoleptic and physical-chemical features of sheep milk and cheese is limited beyond the classical determinations of fat content, protein and total solids, which are not differentiating elements of those animal products. Two experiments have been carried out in Italy with Sarda dairy sheep offered four Mediterranean forage species in two stages: in winter coinciding with early lactation 
and forages in vegetative status, versus spring, when the same forages initiated their reproductive phase, and with ewes in mid-lactation (Addis et al., 2005). The forage species were Lolium rigidum, Hedysarum coronarium, Medicago polymorpha and Chrysanthenum coronarium, and the main interest of the researchers was to determine the effect of forages on the CLA content of milk and cheese, and the content of omega- 3 and omega- 6 acids in forages, milk and cheese. Large differences between forages were found in their omega- 3 and omega- 6 contents, in addition to other chemical parameters. In winter, the voluntary consumptions of these forages varied from 1,580 $\mathrm{g}$ MS daily for Hedysarum to $1,139 \mathrm{~g}$ for Lolium. Likewise, the daily milk yields varied from 2,040 g daily to $1,140 \mathrm{~g}$, while the milk fat contents varied inversely with milk production. Differences in forage intake and milk yield were found again in spring, with Medicago showing the largest intake followed closely by Hedysarum. Maximum milk yield was $1,833 \mathrm{~g}$ with Medicago, followed by $1,170 \mathrm{~g}$ of Lolium. The milk fatty acid profiles differed among forage species, except for C 4:0 and C 17:0. The highest forage consumptions were associated with the higher content of saturated fatty acids, which coincides with the well-known fact that the mammary gland synthesizes mainly saturated fatty acids of 16 carbons or fewer, and that the nature of the response is associated with the energy balance of the animal. The polyunsaturated fatty acids (including CLA), as well as the monounsaturated oleic acid, showed an inverse trend, evidence that at lower consumptions, the animals possibly mobilized higher proportions of adipose tissue. Results were similar during the spring season. Cheese matured for 1 or 60 days showed a fatty acid profile similar to the original milks. The most important conclusion is that both milk and cheese reflected well the differences in the feeding regimen, and that the fatty acid profiles of these products may be manipulated by feeding fresh forages. It is also clear that manipulation of the diet may be confounded with the extent of body fat mobilization, if the diet also affects the energy balance of the animal.

Another experiment carried out in Italy with Sicilo-Sarda sheep compared the effects of ro- tational grazing on Hordeum versus Lolium perenne supplemented daily with $300 \mathrm{~g}$ of concentrate compared with stall-fed animals fed oat hay, silage and $500 \mathrm{~g}$ of the same concentrate (Atti et al., 2006). The grazing treatments did not differ in terms of daily milk production (617 $\mathrm{mL}$ ) and exceeded the stall-fed treatment (363 $\mathrm{mL}$ ). The milk of the latter had a higher fat and protein concentration, but the total yield of both components was higher under grazing; however, cheese yield was not examined. The content of short-chain fatty acids (C4-C10) did not differ among treatments, while the intermediatechain fatty acid (up to C16) levels were higher in barn-fed animals; on the contrary, the polyunsaturated acids were higher in grazing animals, including the CLA (7.3 and $10.3 \mathrm{gL}^{-1}$ for Hordeum and Lolium, respectively, versus 2.4 $\mathrm{gL}^{-1}$ for estabulation). As established with dairy cows, this experiment confirmed the superiority of freshly grazed forages compared to stall-fed treatments in terms of the CLA content.

The effect of different diets offered at several farms varying from hay-based diets, hay plus maize silo, or hay, maize silage and pasture silage was evaluated in Italy (Stefanon et al., 2004). The cheeses were matured for different lengths of time. The authors identified more than 60 volatile compounds that contributed to cheese flavor, and they suggested that the influence of the diet was more related to the processes of chemical and microbial fermentation during maturation than to the direct transference of chemical compounds from milk to cheese. However, it should be noted that the fermentation products are influenced by the substrates available, many of them derived from the feed.

Finally, the effect of the alpine climate on pastures was evaluated in France, and it was determined that the cheeses produced in pastures located in different orientations and differing in botanical composition presented organoleptic differences and differences in the composition of volatile compounds that contribute to flavor and aroma (Buchin et al., 1999).

Regarding a supplement rich in oleic acid such as olive oil pomace ("alpeorujo"), Cabiddu et al. (2004) compared the performance of three 
groups of Sarda sheep from five weeks before birth until the fifth week of lactation. The groups received basal diets of grass hay and concentrates that included 0,250 or $500 \mathrm{~g} \mathrm{DM}$ of pure pomace silage. Total dietary consumption decreased with increasing pomace supplementation: $1,691,1,536$ and $1,384 \mathrm{~g}$ day $^{-1}$ respectively, and the sheep weight loss increased with increasing pomace silage, but that did not led to significant differences in the milk production among the groups, which were 1,602, 1,665 and $1,471 \mathrm{~mL}$ daily, respectively. Growth of the suckling lambs was also unaffected. Similar but less detailed results have been reported for work carried out in Chipre, summarized by Hadjipanayiotou (1999). Chiofalo et al. (2004) supplied a diet of concentrates plus hay to suckling sheep, including 0 or $20 \%$ of partially pitted pomace with or without addition of vitamin E. Addition of vitamin E showed no effects, while pomace feeding resulted in a significant increase in milk production, as well as an increase of the unsaturated:saturated fatty acid ratio, and an improvement of the atherogenic and thrombogenic milk indexes. The rheological milk properties remained unaltered by pomace feeding.

\section{Pastures and sheep milk composition}

The lipids present in forages fluctuate between $3 \%$ and $10 \%$ DM, including: (1) triglycerides (TG), as an energy reserve, (2) phospho-lipids, as members of the cell walls, (3) waxes and cutins, on the external surface, and (4) steroids, with a great variety of biological activities. The polyunsaturated fatty acids are fundamentally present in phospholipids, and, in fact, make a high contribution to total fatty acids: on average, $95 \%$ of these acids consist of C18:3, C18:2 and $\mathrm{C} 16: 0$, and in fresh grass, 18:3 represents $50-75 \%$ of that amount. A strong positive correlation has been found between the 18:3 content and the nitrogen content in forage (Elgersma, 2005). The main sources of variation in the content of fatty acids are species, stage of maturity (Dewhurst et al., 2001), temperature and light intensity. When these lipids are consumed by the ruminant, the first phase of lipolysis is probably carried out by plant lipases. The unsatu- rated fatty acids undergo a high degree of hydrogenation in the rumen, and many fatty acids are incorporated and transformed into bacterial fatty acids, where C16:0, C18:0 and C18:1 are predominant.

As mentioned before, the scientific literature contains few references to milk composition and quality in grazing sheep. Similarly to bovine milk, the profile of fatty acids of sheep milk is altered by the feeding regime (Atti, 2006; Valvo, 2005), by the grass/concentrate ratio (Avondo et al., 2003 mentioned by Biondi et al., 2008) and by forage species and their phenological stage (Addis et al., 2005; Cabiddu et al., 2005).

Following the winter season in Mediterranean Europe, there is a sudden change in feeding regimen, with barn-fed dairy sheep moving from a winter diet of wheat straw and/or hay plus concentrates to a grazing regime. Similarly to observations made in dairy cows (Kuzdzal-Savoie et al., 1961), sheep also respond rapidly to feeding changes. Biondi et al. (2008) examined the daily changes in the milk composition of ten Comisana ewes over 23 consecutive days when moved from the winter diet to an oats/vicia pasture as the only feed source, with an availability of $2.1 \mathrm{~kg}$ DM daily per animal. Milk yields decreased in the first three days, from an average of $570 \mathrm{~g}$ daily to $472 \mathrm{~g}$, but returned to the initial levels on the fourth day. The fat, protein and lactose contents were unaltered, but the fatty acid profile changed. The shorter-chain fatty acids (C4 and C6) were not affected, but there was a striking increase of linolenic, trans-vaccenic and rumenic unsaturated fatty acids during the second and third days of grazing, that stabilized by the eighth day. These changes are important, as sheep milk is mostly transformed into cheese, and cheese processing does not alter the total CLA content or that of its most important isomers (Luna et al., 2005a,b).

In Italy, Addis et al. (2005) sowed pure plots of Lolium rigidum; sulla, Hedysarum coronarium; Medicago polymorpha and Chrysanthemum coronarium to determine how they would affect the composition of sheep milk. Two experiments were made, corresponding to two different seasons: winter during active growth of pastures, 
and spring during the flowering season. Each of the species was cut and fed twice daily to Sarda ewes, and milk production was measured in the last three days of the experimental period. Cheeses with 1 or 60 days of maturation were also analyzed. Milk and cheese compositions were affected by the species of forage in terms of fatty acids, with a strong effect particularly from the dicotyledons. The same group of researchers (Cabiddu et al., 2005) demonstrated the effects of the same forage species when directly grazed and found large changes in the fatty acid profiles associated with forage species, to the extent that a discriminant analysis of the results differentiated the milk from the four species forage with $100 \%$ accuracy.

The results referred to above, as well as those reported by Cabiddu et al. (2005), demonstrate that feeding different forage species induces changes in several milk fatty acids, but the most striking effect is on the entire fatty acid profile, such that the results are generally analyzed with multivariate analysis techniques, such as discriminant and principal-component analyses. Complementarily, indexes such as the atherogenicity and thrombogenicity of Ulbricht and Southgate (1991) are estimated. For example, in the experiments by Addis et al. (2005) with stall-fed sheep, the indices of milk atherogenicity during winter (active growth season) were 1.76, 2.49, 2.17 and 3.32 for $C$. coronarium, $L$. rigidum, $M$. polymorpha and $H$. coronarium, respectively, while the respective values for spring were $0.81,2.50,1.57$ and 3.24. All these differences were significant and were transferred to the respective cheeses. Despite the relative scarcity of data, the information available so far, summarized by Cabiddu et al. (2005), shows that, regardless of the fermentation processes and maturation undergone by cheese, including the partial hydrolysis of triglycerides and phospholipids, with the subsequent liberation of fatty acids, the relative proportions of these acids undergo only small changes. On the other hand, the even more scarce comparative information suggests that CLA originating in the rumen of grazing ruminants is more important than CLA synthesized endogenously from the rumen precursors, as evaluated by the activity of the enzyme $\Delta^{9}$-desaturase (Griinari et al., 2000), and that this phenomenon is more consis- tent in sheep than in cattle. The ratio of rumen CLA to endogenous CLA seems to be inversely related to the leafiness of the forage consumed, which suggests that the higher the contribution of ruminal precursors (for example vaccenic acid) is, the lower is the endogenous synthesis (Cabiddu et al., 2005).

Finally, it is noteworthy that, although the composition of numerous forage species has been studied in terms of very-long-chain fatty acids (saturated, linear chains of $\mathrm{C} 20$ to $\mathrm{C} 34)$, longchain alcohols (C20 to $\mathrm{C} 34)$ and n-alkanes (C21 to $\mathrm{C} 33$ ) with the aim of using these chemical entities as internal indicators of digestibility, consumption and botanical diet composition of grazing ruminants (Dove and Mayes, 2005), they have not been used as possible differentiating elements, possibly because their fecal recovery tends to be very high (and consequently are not transferred into milk); however, their detection in feces would represent a simple indicator of the general type of animal diet, useful for traceability of the feeding strategy. On the other hand, alkenes (unsaturated, C27-C33) are metabolized, and their fecal recovery is lower, thus representing potential differentiation markers for animal products. This is potentially important, as all of these compounds may be determined rapidly by Near Infrared Spectrometry (NIRS), although the technique has apparently not been applied to cheeses yet.

\section{Other differentiating elements in milk}

As indicated in Table 4, the micronutrients present in milk can be used to differentiate the type of feeding received by lactating ruminants (Lucas et al., 2005). In addition, milk carries numerous secondary compounds, in even smaller amounts, many of them reflecting the type of diet received.

Moio et al. (1996) extracted the volatile neutral compounds from milk produced by sheep grazing native grasslands, sown grass pastures or by stall-fed animals receiving a concentrate ration. The compounds were extracted by distillation, followed by concentration, dilution in dichloromethane, and GC/MS analysis. Of the more than 80 analytes present, 70 were identified and 
quantified, including esters, aldehydes, alcohols, ketones, nitrogen and sulfur compounds, aromatic hydrocarbons and lactones. The amounts of these compounds varied according to milk origin, but they were present in all of them. On the contrary, two sesquiterpenes that were identified were only present in milk produced on natural grasslands and in Peccorino-type cheeses produced from that milk. Therefore, the authors suggest that they may be used as chemical markers of the origin of milk and cheese, even though they did not contribute to the aroma of either product. Regardless of the numerous compounds present, only ten of them contributed to determine the aroma of milk and cheese. The authors pointed out that, depending on the concentration, the same compounds may provide pleasant or unpleasant smells when evaluated by GC/ olfactometry, as is the case with varying indole concentration, among others.

An interdisciplinary group of INRA, France, has studied components such as terpenes and carotenes, in addition to fatty acids, as feeding indicators of cow milk (Martin et al., 2005), and found that the terpenes profile is a particularly effective indicator of the type of pasture consumed, while the amount of carotenes and/or milk color allow differentiation between diets of maize silage, hay + concentrates, pasture silage and direct grazing. Similarly, they determined that the profile of milk fatty acids clearly differentiates milk produced based on concentrates versus other alternatives. In fact, in an experiment where six diets were compared, the combination of terpenes and fatty acids enabled the identification of milk from the different treatments with $100 \%$ accuracy.

In the specific case of terpenes, 14 different compounds were analyzed in milk and cheese from cows grazing very diverse alpine grassland, versus a pasture of pure Dacytlis glomera$t a$, and found large differences in the concentration and presence of those compounds. Most of the difference was due to the very low terpene concentration of grass species, whereas dicotyledons tend to be rich in terpenes.

Consequently, pastures with a complex botanical composition are markedly richer in terpenes than monophytic grass pastures (Martin et al.,
2005). Researchers of the same French group (Fernandez et al., 2003) compared milk and cheese produced during the summer grazing season versus winter, on numerous farms in two regions of France: the lowlands in Brittany, and the mountain grasslands of Auvergne. In the case of Brittany, winter feeding was based on maize silage, while hay or prairie silage was used in Auvergne. The analysis of terpenes, and in particular sesquiterpenes, was able to discriminate the milk from both regions and both seasons with total effectiveness.

Beta-carotenes are responsible for the yellowish coloration of milk and adipose tissue in cattle, and originate in forages consumed by animals, including preserved forages. Color measurements have allowed the discrimination of milk derived from concentrates or maize silage from that of pastures, whether grazed or ensiled, but they could not discriminate among hay types (Martin et al., 2005). However, sheep adipose tissue and milk store a lower proportion of carotenes than cattle, and goat milk even less, due to the high activity of the $\beta$-carotene 15,15 ' monooxygenase enzyme (E.C. 1.14.99.36) (Yang et al., 1992; Nozière et al., 2006).

Similarly, the concentration of rumenic acid has been used to differentiate pastures associated with different elevations in the French Alps (Martin et al., 2005). Coulon et al. (2004) summarized information accrued during ten years in France, indicating that, in the case of bovine milk, the effects of the botanical composition of the forage on the intensity of flavors and textures of Abondance, Beaufort and St-Nectaire cheeses were closely associated with pastures of different types, elevation and South-North orientation, to the extent that it was possible to identify the geographic origin of a cheese based on these parameters.

In addition to the differences induced by the macronutrients mentioned before, sensorial differences are also generated by the presence of a variety of plant secondary compounds. The mono- and sesquiterpenes are important components of essential oils, responsible for aromatic properties. These secondary compounds are involved in plant pollination and resistance to predation and act as antimicrobial agents. They are 
relatively abundant in many dicotyledons, while their concentration in grasses is very low (Tornambé, 2006). Mariaca et al. (1997) examined the distribution of mono- and sesquiterpenes in 47 plants of Swiss pastures where cheeses were produced and isolated 47 compounds in alpine and lowland pastures. The authors suggest that the differences in cheese aromas and flavors were associated with the species consumed, their phenological stage, the location and the terpenes present. Important terpenes included beta-ocimene, limonene and trans-beta-caryophyllene.

Cornu et al. (2001) investigated the volatile compounds of nine species present in native grasslands of Auvergne, in Central France, selected by their diversity in terpene content and type. The terpenes were extracted by the "headspace" technique in a solid phase, without the use of distillation, and the extracts were quantified by GC/MS. The poly-dimethyl-siloxane solid phase captured terpenes, alcohols, cyclic ethers and esters. Four of the nine species studied produced more than 60 volatile compounds, and the authors conclude that some of the terpenes found in higher amounts in these plants could help in establishing the connection among dairy products and the pastures used, in order to improve the traceability of those products. In a follow-up study, the same group of researchers (Tornambé et al., 2006) analyzed milk for the presence of terpenes and isolated 20 mono- and 23 sesquiterpenes. The most abundant monoterpenes were beta-pinene, alpha-pinene, gammaterpinene, limonene, alpha-tujene, terpinolene and alpha-phellandrene. Among the most abundant sesquiterpenes were included beta-caryophyllene, alpha-copaene, beta-cedrene, transmuurola-4(14-),5-diene, beta-bisabolene and gamma-cadinene. In general, the same compounds found in grassland species were found in milk, but there were temporary differences and differences associated with pasture management, which, according to the authors, calls into question some of the specifications of the Products with Denomination of Origin, unless they are associated with management practices of specified pastures.

Viallon (2000) investigated the transfer of terpenes from two very contrasting forage species, Dacytlis glomerata, very poor in terpenes, and the dicot Achillea millefolium, rich in those compounds, to bovine milk. The experiment demonstrated the transference of monoterpenes in $8 \mathrm{~h}$, while sesquiterpenes appeared in the third milking, $32 \mathrm{~h}$ after the change in diet. After returning to the pure grass diet, the terpenes disappeared from milk in four days. Discussing the headspace technique for volatile compound determination, Toso et al. (2002) analyzed milk from 12 farms in Italy, selected for similarities in management, breed and level of production, with the farms grouped according to the type of feeding: (1) hay, (2) hay + maize silage; and (3) hay + maize silage + prairie silage. They isolated and identified 41 volatile compounds; quantitatively; the most important were ketones (eight compounds, $\left.170 \mathrm{mg} \mathrm{kg}^{-1}\right)$, aldehydes $(0.63 \mathrm{mg}$ $\left.\mathrm{kg}^{-1}\right)$, alcohols (8.36 mg kg-1) and lower amounts of hydrocarbons, sulfur compounds, esters and terpenes. The discriminant analysis of the results selected nine compounds that classified $100 \%$ of the original samples correctly: acetone, 2,3-butanedione, 2-butanone, ethanol (probably originating from silage fermentation), acetaldehyde, ethyl acetate, ethyl isovalerate and dimethylsulphone.

The headspace technique has been used to analyze Spanish DOP cheeses (Barron et al., 2005a; Barron et al., 2001) and also to compare differences in the extraction procedure. In the case of Idiazabal cheese, manufactured with raw sheep milk, the results showed significant differences in milk chemical and bacteriological properties and sensorial differences in the resulting cheeses. These parameters would help to adjust cheese manufacturing techniques in order to obtain a more uniform product. Similarly, La Serena cheese, made with raw Merino milk using an extract of the thistle Cynara cardunculus as a coagulant, also showed seasonal variations (Carbonell et al., 2002; Fernández-García et al., 2002), although the alcohols and esters were predominant over the whole year, with an important terpene presence in spring, where the main chemical entities were the same terpenes detected in the alpine pastures of France by Mariaca et al. (1997). Similar results were seen in the analyses by Moio et al. (1996) and Fernández-García et al. (2002), who found that a relatively small number of compounds (16) could be used to discriminate Manchego cheeses of dif- 
ferent origins and those produced with pasteurized milk or raw milk with complete accuracy.

From this section of the literature review, it may be inferred that, in seasons with active grass growth and if there is an important presence of dicotyledons (what is "important" has not been defined, in terms of botanical composition), it is very reasonable to expect the presence of terpenes, while there may be an important presence of hydrocarbons, alcohols, aldehydes and ketones in milk throughout the whole year. It is therefore important to precisely define the botanical composition of the grasslands used, as a base parameter to establish if they contribute, and to what extent, to the chemical compounds responsible for product differentiation.

It is also clear that the feeding strategy, animal, and pasture management, as well as the presence of odors in, or close, to the milking shed, will generally affect the volatile compounds of the resulting milk and cheese. The chemical features in the resulting cheeses are definitely useful to ensure or monitor the traceability of not only milk and cheese, but also meat (Prache et al., 2005).

The feasibility of commercial application of these measurements is therefore related to cost; the colorimetric methods to quantify the carotenoid concentrations in fat are immediately applicable, while more sophisticated methods based on chromatography are obviously more expensive (Prache et al., 2005), but their occasional use will hinder frauds and false identifications of animal products. In addition, the rapid advances being achieved in the application of NIRS techniques (for example, for the quantification of fatty acids and polyphenols) as well as diverse molecular techniques ensures that sophisticated and inexpensive analytic methods will be available in the short and medium term for the determination of micro-compounds.

\section{Methodological and instrumental conclusions}

From the literature reviewed, mainly of European origin and with a particular emphasis on
Spain, Italy and France, it is evident that the measurement of secondary metabolites that could supply typical, functional or typicity features to forages, feeds, and animal products, requires more sophisticated techniques than the those usually used to determine conventional parameters, such as nitrogen, fat and lactose contents.

Gas chromatography (GC) is the most widely adopted technique for determining fatty acids, terpenes and hydrocarbons, using long state of the art columns that require previous stages of sample preparation. The latter may be quite elaborate, depending on the accuracy desired, and the more or less precise characterization of the individual compounds. One example is the determination of terpenes and essential oils and, in general, volatile compounds responsible for aromas and flavors, the determination of which utilizes headspace samples among others. It should be remembered that the columns used in GC for these different compounds are generally different than the columns used to quantify fatty acids; therefore, the same sample is occasionally subject to GC in more than one column.

Analyses become more complicated if the chemical compounds present in the sample are unknown beforehand; in that case, the use of GC with a mass detector is required. An example is the characterization of Idiazabal cheese, referred to above. Fortunately, previous research has already identified some compounds as excellent candidates, present in variable degree, in all of the cheeses analyzed to date.

The quantitation of polyphenols requires different instrumentation. Determinations of total polyphenols, hydrolyzable or not, are simple and only require spectrophotometry. Conversely, determination of specific polyphenols requires High Pressure Liquid Chromatography (HPLC), equipped with proper columns and detectors. The very recent development of an HPLC technique to separate important groups of phenols, water soluble and liposoluble vitamins, carotenoids and chlorophyll (Mendiola et $a l ., 2008)$ in functional foods in a single pass is particularly interesting and new developments on this technique are expected soon. 


\section{Conclusions on functionality}

From the literature review, it may be inferred that, in seasons with active grass growth and if there is an important presence of dicotyledons (although "important" has not been defined yet, in terms of botanical composition), it is very reasonable to expect the presence of numerous secondary metabolites in small but significant amounts, such as terpenes, some polyphenols and fatty acids, while there may be an important presence of hydrocarbons, alcohols, aldehydes and ketones in milk over the whole year. However, accurately defining the botanical composition of the grasslands used is required as a base parameter to establish if and to what extent they contribute differentiating chemical compounds. If that is indeed the case, these findings would represent an additional stimulus for the conservation of plant genetic resources.

In general, it is clear that the feeding strategy and the animal and pasture management, as well as the presence of odors in, or close to, the milking barn will affect the milk volatiles and the resulting cheese. The chemical features in the resulting cheeses are definitely useful to ensure or monitor the traceability of milk and cheese, as well as for meat traceability (Prache et al., 2005).
The feasibility of commercial application of these measurements is strongly related to cost; the colorimetric methods to quantify carotenoid concentrations in fat or total polyphenols in grasses and cheeses are of immediate application, while more sophisticated methods based on chromatography are currently more expensive (Prache et al, 2005), but their occasional use will avoid fraud and false identification of the animal products. This is, definitively, the predominant tendency in the most demanding international markets. In addition, rapid advances in the application of NIRS techniques (for example, for quantification of fatty acids, polyphenols, hydrocarbons, etc.), as well as diverse molecular techniques ensure that, in the short term, cheaper and more sophisticated techniques will become available for the determination of micro-compounds in milk and cheese quality-control processes, particularly those intended to identify functional and differentiating characteristics.

\section{Acknowledgements}

The authors gratefully acknowledge the comments received from Mertxe de Renobales Scheifler, Departamento de Bioquímica and Biología Molecular, Facultad de Farmacia, Universidad of the País Vasco, Spain.

\section{Resumen}

R.R. Vera, C. Aguilar y R. Lira. 2009. Diferenciación de la leche y queso de oveja en base a calidad y composición. Cien. Inv. Agr. 36(3):307-328. La rentabilidad de la producción ovina tradicional entre productores pequeños y medianos es muy baja, razón por la cual es deseable buscar alternativas con mayor valor agregado y diferenciación. Una alternativa de interés es la producción de leche ovina para la elaboración de quesos. El artículo analiza y discute las alternativas para modificar la composición de la leche y quesos de forma de diferenciarlos. Se discute como es posible cuantificar objetivamente dichos cambios y se mencionan brevemente algunas de las técnicas analíticas disponibles con ese fin. En general, los esfuerzos que se están realizando a nivel mundial se focalizan en la modificación del contenido y perfil de los ácidos grasos, así como la identificación y cuantificación de compuestos volátiles, terpenos, polifenoles y otros que permitirían diferenciar quesos y leche por sabor y olor, y que permiten asegurar la trazabilidad.

Palabras clave: Ovinos, leche, queso, sabor, composición, diferenciación, valor agregado. 


\section{References}

Addis, M., A. Cabiddu, G. Pinna, M. Decandia, G. Piredda, A. Pirisi, and G. Molle. 2005. Milk and cheese fatty acid composition in sheep fed mediterranean forage with reference to conjugated linoleic acid cis-9, trans-11. Journal of Dairy Science 88: 3443-3454.

Aguilar, C., R. R. Vera, P. Toro, R. Lira, J. Quenaya, F. Squella, H. Yutronic, P. Pérez, I. Peña, L. Barrales, and I. Briones, I. 2008. Lamb fattening on Mediterranean-like pastures in Chile versus olive oil cake-based rations. International Grassland Congress, Volume II. Hohout, China. p. 162.

Alderman, G. 1997. Responses in the yield of milk constituents to the intake of nutrients by dairy cows. CABI: Biotechnology and Biological Sciences Research Council. Technical Committee on Responses to Nutrients, Wallingford, U.K. 96 p.

Annison, E. F., D. B. Lindsay, and J. Nolan. 2002. Digestion and metabolism. In: M. Freer and H. Dove (eds.). Sheep Nutrition. CABI, Wallingford, U. K. p. 95-118.

Atti, N., H. Rouissi, and M. H. Othmane. 2006. Milk production, milk fatty acid composition and conjugated linoleic acid (CLA) content in dairy ewes raised on feedlot or grazing pasture. Livestock Science 104: 121-127.

Avendaño, J., F. Fernández y C. Sandoval. 2002. Comparación de la producción láctea de tres grupos raciales de ovejas en la zona Centro-Sur de Chile. Agricultura Técnica 62. 530-540.

Barron, L.J.R., E. F. de Labastida, S. Perea, F. Chávarri, C. de Vega, M. S. Vicente, M. I. Torres, A. I. Nájera, M. virto, A. Santisteban, F. J. PérezElortondo, M. Albisu, J. Salmerón, C. Mendía, P. Torre, F. C. Ibañez, and M. de Renobales. 2001. Seasonal changes in the composition of bulk ewe's milk used for Idiazabal cheese manufacture. International Dairy Journal 11: 771-778

Barron, L. J. R., Y. Redondo, M. Ortigosa, M. Carbonell, S. García, P. Torre, M. de Renobales, and E. Fernández-García. 2005a. Comparison of dynamic headspace methods used for the analysis of the volatile composition of Spanish PDO ewe's raw milk cheeses. Lait 85: 491-513.

Barron, L. J. R., Y. Redondo, M. Aramburu, J. Pérez-Elortondo, M. Abisu, A. I. Nájera, and M. de Renobales. 2005b. Variations in volatile compounds and flavour in Idiazabal cheese manufac- tured from ewe's milk in farmhouse and factory. Journal of the Science in Food and Agriculture $85: 1660-1671$

Barry, T. N. , D. M. McNeill, and W. McNabb. 2001. Plant secondary compounds: their impact on forage nutritive value and upon animal production. Proceedings of the XIX International Grassland Congress 19: 445-452.

Bencini, R., and G. Pulina. 1997. The quality of sheep milk: a review. Australian Journal of Experimental Agriculture 37: 485-504.

Bencini, R, T. W. Knight, and P. Hartmann. 2003. Secretion of milk and milk components in sheep. Australian Journal of Experimental Agriculture 43: 529-534.

Berard, J., F.Bianchi, M. Careri, A. Chatel, A. Mangia, and M. Musci. 2007. Characterization of the volatile fraction and of free fatty acids of "Fontina Valle d'Aosta", a protected designation of origin Italian cheese. Food Chemistry 105: 293300

Besle, J. M., J. L. Lamaison, B. Dujol, P. Pradel, D. Fraisse, D. Viala, and B. Martin. 2005. Flavonoids and other phenolics in milk as a putative tool for traceability of dairy production systems. In: J. F. Hocquette and S. Gigli (eds.), Indicators of milk and beef quality. EAAP Publication No. 112, Wageningen Academic Publishers, Wageningen, Holland. p. 345-350.

Biondi, L., M. A. Valvo, M. Di Gloria, E.S. Tenghi, V. Galofaro, and A. Priolo. 2008. Changes in ewe milk fatty acids following turning out to pasture. Small Ruminant Research 75: 17-23.

Bu, D.P., J. Q. Wang, T.R. Dhiman, and S.J. Liu. 2007. Effectiveness of oils rich in linoleic and linolenic acids to enhance conjugated linoleic acid in milk from dairy cows. Journal of Dairy Science 90: 998-1007.

Buchin, S., B. Martin, D. Dupont, A. Bornard, and C. Achilleos. 1999. Influence of the composition of Alpine highland pasture on the chemical, rheological and sensory properties of cheese. Journal of Dairy Research 66: 579-588.

Cabiddu, A., M. Canu, M. Decandia, R. Pompei, and G. Molle. 2004. The intake and performance of dairy ewes fed with different levels of olive cake silage in late pregnancy and suckling periods. In: Ben Salem H., A. Nefzaoui and P. Morand-Fehr (eds). Nutrition and Feeding Strategies of Sheep and Goats under Harsh Climates, CIHEAMIAMZ, Zaragoza, Spain. p. 197-202.

Cabiddu, A., M. Decandia, M. Addis, G. Piredda, A. 
Pirisi, and G. Molle. 2005. Managing Mediterranean pastures in order to enhance the level of beneficial fatty acids in sheep milk. Small Ruminant Research 59: 169-180.

Carbonell, M., M. Nuñez, and E. Fernández -García. 2002. Seasonal variation of volatile compounds in ewe raw milk La Serena cheese. Lait 82: 699711.

Chilliard, Y., A. Ferlay, R. M. Mansbridge, and M. Doreau. 2000. Ruminant milk fat plasticity: nutritional control of saturated, polyunsaturated, trans and conjugated fatty acids. Annales de Zootechnie 49: 181-205.

Chiofalo, B., L. Liotta, A. Zumbo, and V. Chiofalo. 2004. Administration of olive cake for ewe feeding: effect on milk yield and composition. Small Ruminant Research 55: 169-176.

Cornu, A., A.-P. Carnat, B. Martin, J. B. Coulon, J. L. Lamaison, and J. L. Berdagué. 2001. Solid-phase microextraction of volatile components from natural grassland plants. Journal of Agricultural and Food Chemistry 49: 203-209.

Coulon, J. B., A. Delacroix-Buchet, B. Martin, and A. Pirisi. 2004. Relationships between ruminant management and sensory characteristics of cheeses: a review. Lait 84: 221-241.

de Lorgeril, M. and P. Salen. 2004. Use and misuse of dietary fatty acids for the prevention and treatment of coronary heart disease. Reproduction, Nutrition and Development 44: 283-288.

Demeyer, D. and M. Doreau. 1999. Targets and procedures for altering ruminant meat and milk lipids. Proceedings of the Nutrition Society 58: 593-607.

Dewhurst, R.J., N. Scollan, S.J. Youell, J.K.S. Tweed, and M.O. Humphreys. 2001. Influence of species, cutting date and cutting interval on the fatty acid composition of grasses. Grass and Forage Science 56: 68-74.

Dewhurst, R. J., K. J. Shingfield, M. R. F. Lee, and N. D. Scollan. 2006. Increasing the concentrations of beneficial polyunsaturated fatty acids in milk produced by dairy cows in high-forage systems. Animal Feed Science and Technology 131: 168-206.

Dove, H. and R. W. Mayes. 2005. Using n-alkanes and other plant wax components to estimate intake, digestibility and diet composition of grazing/browsing sheep and goats. Small Ruminant Research 59: 123-139.

Durand, D., V. Scislowski, D. Gruffat, Y. Chilliard, and D. Bauchart. 2005. High-fat rations and lipid peroxidation in ruminants: consequences on the health of animals and quality of their products. In: J. F. Hocquette and S. Gigli (eds.), Indicators of Milk and Beef Quality. Wageningen Academic Publishers, Wageningen, Holland. p. 137-150..

Elgersma, A.(ed.). 2005. Proceedings of the Frontis workshop on fresh herbage for dairy cattle: the key to a sustainable food chain. Wageningen University, Wageningen, Holland. 245 p.

Fernandez, C. C., J. Astier, E. Rock, J. B. Coulon, and J. L. Berdagué. 2003. Characterisation of milk by analysis of its terpene fractions. International Journal of Food Science and Technology 38: 445-451.

Fernández-García, E., M. Carbonell, and M. Nuñez. 2002. Volatile fraction and sensory characteristics of Manchego cheese. 1. Comparison of raw and pasteurized milk cheese. Journal of Dairy Research 69: 579-593.

Foegeding., E. A. and M. A. Drake. 2007. Invited Review: Sensory and Mechanical Properties of Cheese Texture. Journal of Dairy Science 90: 1611-1624.

Freer, M. 2002. The nutritional management of grazing sheep. In: M. Freer and H. Dove (eds.). Sheep Nutrition. CABI, Wallingford, UK. p. 357-375.

Gomez-Cortes, P., P. Frutos, A. R. Mantecon, M. Juarez, M.A.de la Fuente, and G. Hervas. 2008. Milk production, conjugated linoleic acid content, and in vitro ruminal fermentation in response to high levels of soybean oil in dairy ewe diet. Journal of Dairy Science 91: 1560-1569.

Griinari, J.M., B.A.Corl, S. H. Lacy, P. Y. Chouinard, K. V. V . Nurmela, and D. E. Bauman. 2000. Conjugated linoleic acid is synthesized endogenously in lactating dairy cows by DELTA9-desaturase. Journal of Nutrition 130: 2285-2291.

Hadjipanayiotou, M. 1999. Feeding ensiled crude olive cake to lactating Chios ewes, Damascus goats and Friesian cows. Livestock Production Science 59: 61-66.

Haenlein, G. F. W. 2000. The Nutritional Value of Sheep Milk. www.sheepdarying.com/haenlein. htm (Consulted 20 February 2007).

Haug, A., A. T. Hostmark, and O. M. Harstad. 2007. Bovine milk in human nutrition - a review. Lipids in Health and Disease 6: 31-52.

Hepp, C (ed.). 1998. Avances y Perspectivas de la Lechería de Ovejas. INIA Tamel- Aike, Coyhaique, Chile. 132 p.

Hervé, M. y R. Vidal. 1998. Experiencia reciente en producción de leche de oveja en el Valle Cha- 
cabuco, Aysen, Patagonia. In: C. Hepp (ed.). Avances y Perspectivas de la Lechería de Ovejas, 92-104. INIA, Tamel-Aike, Coyahique, Chile. p. 92-104.

Hocquette, J. F. and S. Gigli (eds.). 2005. Indicators of Milk and Beef Quality. EAAP Publication No. 112. Wageningen Academic Publishers, Wageningen, Holland. 464 p.

Huth, P. J., D. B. DiRienzo, and G. D. Miller. 2006. Major scientific advances with dairy foods in nutrition and health. Journal of Dairy Science 89: 1207-1221.

Jensen, R.G. 2002. The composition of bovine milk lipids: January 1995 to December 2000. Journal of Dairy Science 85: 295-350.

Kirk, R. S., R. Sawyer y H. Egan. 2006. Composición y Análisis de Alimentos de Pearson. CECSA, México. 777 p.

Kris-Etherton, P. M., T. A. Pearson, Y. Wan, R. L. Hargrove, K. Moriarty, V. Fishell, and T. D. Etherton. 1999. High-monounsaturated fatty acid diets lower both plasma cholesterol and triacylglycerol concentrations. American Journal of Clinical Nutrition 70: 1009-1015.

Kusanovic, S. 1998. Experiencia sobre ordeñe de ovejas en Magallanes. In: C. Hepp (ed.), Avances yPerspectivas de la Lechería de Ovejas. INIA, Tamel-Aike, Coyahique, Chile. p. 82-91.

Kuzdzal-Savoie, S. and W. Kuzdzal. 1961. Influence de la mise a l'herbe des vaches latieres en differents acides gras poly-insaturés. Lait 41: 369398.

Labussiere, J., P. Pétrequin, J. F. Combaud et B. Mirman. 1969. Relations entre l'aptitude a la traite des brevins et la perte de production laitiere constatés au moment du sevrage. Annales de Zootechnie 18: 5-15.

Larráyoz, P., M. T. Martínez, L. J. R. Barrón, P. Torres, and Y. Barcina. 1999. The evolution of free fatty acids during the ripening of Idiazábal cheese; influence of rennet type. European Food Research and Technology 210: 9-12.

Lucas, A., J. B. Coulon, P. Grolier, B. Marin, and E. Rock. 2005. Nutritional quality of dairy products and human health. In: J. F. Hocquette and S. Gigli (eds.), Indicators of Milk and Beef Quality. Wageningen Academic Publishers, Wageningen, Holland. p. 163-178.

Luna, P., J. Fontecha, M. Juárez, and M. A. de la Fuente. 2005b. Conjugated linoleic acid in ewe milk fat. Journal of Dairy Research 72: 415-424.
Luna, P., M. A. de la Fuente, and M. Juárez. 2005a. Conjugated linoleic acid in processed cheeses during the manufacturing stages. Journal of Agricultural and Food Chemistry 53: 2690-2695.

Luna, P., A. Bach, M. Juarez, and A. de la Fuente. 2008. Effect of a diet enriched in whole linseed and sunflower oil on goat milk fatty acid composition and conjugated linoleic acid isomer profile. Journal of Dairy Science 91: 20-28.

Lundén, A. 2005. Genetic markers of milk quality in cows. In: J. F. Hocquette and S. Gigli (eds.). Indicators of Milk and Beef Quality. Wageningen Academic Publishers, Wageningen, Holland. p. 33-46.

Mariaca, R. G., T. F. H. Berger, R. Gauch, M. I. Imhof, B. Jeangros, and J. O. Bosset. 1997. Occurrence of volatile mono- and sesquiterpenoids in highland and lowland plant species as possible precursors for flavor compounds in milk and dairy products. Journal of Agricultural and Food Chemistry 45: 4423-4434.

Martin, B., A. Cornu, N. Kondjoyan, A. Ferlay, I. Verdier-Metz, P. Pradel, E. Rock, Y. Chilliard, J. B. Coulon and J. L. Berdegué. 2005. Milk indicators for reconingzing the types of forages eaten by dairy cows. In: J. F. Hocquette and S. Gigli (eds.). Indicators of Milk and Beef Quality. Wageningen Academic Publishers, Wageningen, Holland. p. 127-136.

McSweeney, P.L.H. and M. J. Sousa. 2000. Biochemical pathways for the production of flavour compounds in cheeses during ripening: A review. Lait 80: 293-324.

Mele, M., A. Buccioni, and A. Serra. 2004. Lipid requirements in the nutrition of dairy ewes. Italian Journal of Animal Science 4: 53-62.

Mendiola, J. A., F. R. Marin, J. J. Señoráns, G. Reglero, P. J. Martín, A. Cifuentes and E. Ibañez. 2008. Profiling of different bioactive compounds in functional drinks by high-performance liquid chromatography. Journal of Chromatography A 1188: 234-241.

Moio, L., L. Rillo, A. Ledda and F. Addeo. 1996. Odorous constituents of ovine milk in relationship to diet. Journal of Dairy Science 79: 13221331.

Moltó-Puigmartí, C., A. I. Castellote. and M. C. López-Sabater. 2007. Conjugated linoleic acid determination in human milk by fast-gas chromatography. Analytica Chimica Acta 602: 122-130.

Mosley, E. E., G. L. Powell, M. B. Biley, and T. C. Jenkins. 2002. Microbial biohydrogenation of 
oleic acid to trans isomers in vitro. Journal of Lipid Research 43: 290-296.

Nicolosi, R. J., B. Woolfrey, T. A. Wilson, P. Scolling, G. Handelman and R. Fisher. 2004. Decreased aortic early atherosclerosis and associated risk factors in hypercholesterolemic hamsters fed a high- and mid-oleic acid oil compared to a highlinoleic acid oil. Journal of Nutritional Biochemistry 15: 540-547.

Noziere, P., B. Graulet, A. Lucas, B. Martin, P. Grolier, and M. Doreau. 2006. Carotenoids for ruminants: From forages to dairy products. Animal Feed Science and Technology 131: 418-450.

Ostrowska, E., F. R. Dunshea, M. Muralitharan, and R. F. Cross. 2000. Comparison of silver-ion high performance liquid chromatographic quantification of free and methylated conjugated linoleic acid. Lipids 35: 1147-1153.

Ovalle, M. C. and F. Squella. 1996. Terrenos de pastoreo con pastizales anuales en el área de influencia climática mediterránea. In: N. I. Ruiz (ed.). Praderas para Chile. INIA, Sanitago, Chile. p. 429-466.

Pacheco, Y. M., B. Bermúdez, S. López, R. Abia, J. Villar, and F. J. G. Muriana. 2006. Ratio of oleic to palmitic acid is a dietary determinant of thrombogenic and fibrinolytic factors during the postprandial state in men. American Journal of Clinical Nutrition 84: 342-349.

Palmquist, D. L. 2006. Modifying milk composition to increase use of dairy products in healthy diets. Animal Feed Science and Technology 131: 149-153.

Park, Y. W. 2007. Rheological characteristics of goat and sheep milk. Small Ruminant Research 68: 73-87.

Pinho, O., I.M.P.L.V.O. Ferrerira, and M. A. Ferrerira. 2002. Solid-phase microextraction in combination with GC/MS for quantification of the major volatile free fatty acids in ewe cheese. Analytical Chemistry 74: 5199-5204.

Poveda, J. M. and L. Cabezas. 2006. Free fatty acid composition of regionally-produced Spanish goat cheese and relationship with sensory characteristics. Food Chemistry 95: 307-311.

Prache, S., A. Cornu, J. L. Berdagué, and A. Priolo. 2005. Traceability of animal feeding diet in the meat and milk of small ruminants. Small Ruminant Research 59: 157-168.

Ramalho Ribeiro, J. M., A. E. M. Horta, C. Mosconi, and A. Rosati. 2006. Animal products from the Mediterranean area. Wageningen Academic Pub- lishers, Wageningen. Holland. 342 p.

Ramírez-Restrepo, C.A, T. N. Barry W. Pomroy, N. López-Villalobos, W. McNabb, and P. D. Kemp. 2005. Use of Lotus corniculatus containing condensed tannins to increase summer lamb growth under commerical dryland farming conditions with minimal anthelmintic drench input. Animal Feed Science and Technology 122: 197-217.

de Renobales, M., Rodríguez Barrón, L., Nájera Ortigosa, A.I., Ruiz de Gordoa Arróniz, J.C. y Virto Lecuona, M. 2008. Quesos, lípidos y salud. Alimentación, Nutrición y Salud 15:80-88.

Rubinson, K. A. y J. F. Rubinson .2000. Análisis Instrumental. Prentice Hall, Madrid, España. 847 p.

Sablé, S. and G. Cottenceau. 1999. Current knowledge of soft cheeses flavor and related compounds. Journal of Agricultural and Food Chemistry 47: 4825-4836.

Sanz Sampelayo, M. R., Y. Chilliard, P. Schmidely, and J. Boza. 2007. Influence of type of diet on the fat constitutents of goat and sheep milk. Small Ruminant Research 68: 42-63.

Schreurs, N. M., W. C. McNabb, M. H. Tavendale, G. A. Lane, T. N. Barry, T. Cummings, K. Fraser, N. López-Villalobos, and C. A. Ramírez-Restrepo. 2007. Skatole and indole concentration and the odour of fat from lambs that had grazed perennial ryegrass/white clover pasture or Lotus corniculatus. Animal Feed Science and Technology 138: 254-271.

Schroeder, G. F., G. A. Gagliostro, F. Bargo, J. E. Delahoy, and L. D. Muller. 2004. Effects of fat supplementation on milk production and composition by dairy cows on pasture: a review. Livestock Production Science 86: 1-18.

Scintu, M. F. and G. Piredda. 2007. Typicity and biodiversity of goat and sheep milk products. Small Ruminant Research 68: 221-231.

Sinclair, L.A., Lock, Early, and D. E. Bauman. 2007. Effect of trans-10, cis-12 conjugated linoleic acid on ovine milk fat synthesis and cheese properties. Journal of Dairy Science 90: 3326-3335.

Singh, T. K., M. A. Drake, and K. R. Cadwallader. 2003. Flavor of Cheddar cheese: a chemical and sensory perspective. Comprehensive Reviews in Food Sciences and Food Safety 2: 166-189.

Stefanon, B. and G. Procida. 2004. Effects of including silage in the diet on volatile compound profiles in Montasio cheese and their modification during ripening. Journal of Dairy Research 71: 58-65. 
Stephan, A., M. Bücking, and H. Steinhart. 2000. Novel analytical tools for food flavours. Food Research International 33: 199-209.

Sukhija, P. S. and D. L. Palmquist. 1988. Rapid method for determination of total fatty acid content and composition of feedstuffs and feces. Journal of Agricultural and Food Chemistry 36: 1202-1206.

Tornambé, G., A., P. Cornu, P. Pradel, N. Kondjoyan, A.-P. Carnat, M. Petit, and B. Martin. 2006. Changes in terpene content in milk from pasture-fed cows. Journal of Dairy Science 89: 2309-2319.

Toso, B., G. Procida, and B. Stefanon. 2002. Determination of volatile compounds in cows' milk using headspace. Journal of Dairy Research 69: 569-577.

Treacher, T. T. and G. Caja. 2002. Nutrition during lactation. In: M. Freer and H. Dove (eds.). Sheep Nutrition. CABI, Wallingford, U.K. p. 213-236.

Ulbricht, T.L. and D. A. Southgate. 1991. Coronary heart disease: seven dietary factors. The Lancet 338: 985-992.

Valvo, M.A., M. Lanza, M. Bella, V. Fasone, M. Scerra, L. Biondi, and A. Priolo. 2005. Effect of ewe feeding system (grass v. concentrate) on intramuscular fatty acids of lambs raised exclusviely on maternal milk. Animal Science 81: 431436.

Vera, R., C. Aguilar, R. Lira, I. Peña, J. Quenaya, H. Yutronic, F. Squella, P. Toro and I. Briones. 2008. Fatty acid profile of subcutaneous fat in lambs finished on Mediterranean-like pastures in Chile versus olive oil cake-based rations, International Grassland Congress, Vol II, Houhot, China. p. 162.
Viallon, C., B. Martin, I. Verdier-Metz, P. Pradel, J. P. Garel, J. B. Coulon, and J. L. Berdagué. 2000. Transfer of monoterpenes and sesquiterpenes from forages into milk fat. Lait 80: 635-641.

Virto, M., F. Chávarri, M. A. Bustamante, L. J. R. Barron, M. Aramburu, M. S. Vicente, F. J. Pérez-Elortondo, M. Albisu, and M. de Renobales. 2003. Lamb rennet paste in ovine cheese manufacture, lipolysis and flavour. International Dairy Journal 13: 391-399

Vlaeminck, B., V. Fievez, A. R. J. Cabrita, A. J. M. Fonseca, and R. J. Dewhurst. 2006. Factors affecting odd- and branched-chain fatty acids in milk: a review. Animal Feed Science and Technology 131: 389-417.

Walker, G. P., F. R. Dunshea, and P. T. Doyle. 2004. Effects of nutrition and management on the production and composition of milk fat and protein: a review. Australian Journal of Agricultural Research 55: 1009-1028.

Yang, A., T., W. Larsen, and R. K. Tume. 1992. Carotenoid and retinal concentrations in serum, adipose tissue and liver and carotenoid transport in sheep, goats and cattle. Australian Journal of Agricultural Research 43: 1809-1817.

Yurawecz, M.P., J. K. G. Kramer, and Y. Ku. 1999. Methylation procedures for conjugated linoleic acid. In: Yurawecz, M.P. and Mossoba, M.M. (eds.) Advances in Conjugated Linoleic Acid Research. American Oil Chemists' Society, Champaign, Illinois, USA. p. 64-82.

Zlatanos, S., K. KLaskaridis, C. Feist, and A. Sagredos. 2002. CLA content and fatty acid composition of Greek Feta and hard cheeses. Food Chemistry 78: 471-477. 
